\title{
Simulation of the December 2014 Nemuro Storm Surge and Incident Waves
}

\author{
Jeremy D. BRICKER ${ }^{1}$, Volker ROEBER ${ }^{2}$, Yo FUKUTANI 3 , and Shuichi KURE ${ }^{4}$ \\ ${ }^{1}$ Member of JSCE, Associate Professor, International Research Institue of Disaster Science, Tohoku University \\ (468-1 AzaAoba, Aramaki, Aoba-ku, Sendai 980-0845, Japan) \\ E-mail:bricker@irides.tohoku.ac.jp \\ ${ }^{2}$ Assistant Professor, International Research Institue of Disaster Science, Tohoku University \\ (468-1 AzaAoba, Aramaki, Aoba-ku, Sendai 980-0845, Japan) \\ E-mail:roeber@irides.tohoku.ac.jp \\ ${ }^{3}$ Senior Researcher, Tokio Marine Nichido \\ (1-2-1 Marunouchi, Chiyoda-ku, Tokyo 100-0005, Japan) \\ E-mail:fukutani@irides.tohoku.ac.jp \\ ${ }^{4}$ Member of JSCE, Assistant Professor, International Research Institue of Disaster Science, Tohoku University \\ (468-1 AzaAoba, Aramaki, Aoba-ku, Sendai 980-0845, Japan) \\ E-mail:kure@irides.tohoku.ac.jp
}

\begin{abstract}
The storm surge due to the December 2014 Nemuro cyclone was hindcast using the Delft-3D/SWAN combined hydrodynamic and wave model with Japan Meteorological Agency (JMA) Mesoscale Model (MSM) reanalysis data as the surface boundary condition. Wind and pressure fields near Nemuro from the JMA MSM reanalysis data set agree with data from AMEDAS weather stations in eastern Hokkaido. The storm surge model result matches published measurements of water level and inundation extent in the town. Via application of the BOSZ Boussinesq-type wave model, the excitation of infragravity motions nearshore by this storm were found to be insignificant, but wave runup does cause an increase in the extent of inundation compared to that due to the still water storm tide hindcast by the Delft-3D/SWAN model.

To evaluate the possible effects of climate change, a hypothetical storm with $150 \%$ the intensity of the 2014 cyclone was also simulated. Though the concrete armor units protecting the town's infrastructure are strong enough to escape damage from the hypothetical storm's waves, they are not high enough to prevent waves from riding atop the storm surge into low-lying areas of the town proper and the harbor. These waves are large enough to wreck residential buildings and pose a threat to life as well as property. Coastal hazards at locations in the midlatitudes, such as Nemuro, need to be reassessed accounting for the predicted effects of climate change, and adaptation strategies formulated based on local conditions.
\end{abstract}

Key Words : extratropical cyclone, storm surge, waves, meteorological model, armor unit, breakwater

\section{INTRODUCTION}

The extratropical cyclone of December 17, 2014 caused a storm surge that flooded the downtown and port areas of Nemuro, Hokkaido Prefecture (Fig. 1). Inundation was up to $1.5 \mathrm{~m}$ deep ${ }^{1)}$, necessitating the evacuation of 1,500 residents $^{2)}$, flooding 97 buildings up to $300 \mathrm{~m}$ from shore, and causing damage of over 2 billion yen ${ }^{3)}$. The peak of the storm surge occurred near a neap high tide; if the same event were to occur during a spring high tide, the flooding could be much worse. Due to climate change, it is expected that tropical cyclones will affect higher latitudes ${ }^{4)}$ and the intensity and frequency of extratropical storms near northern Japan may also increase ${ }^{5)}$, exacerbating the coastal flood hazard along Hokkaido's coasts and requiring both the reassessment of coastal defenses already in place and investigation of the necessity for expanded coastal defenses in populated areas.

Section 2 of this paper discusses the meteorological data used to reconstruct the pressure and wind fields of the cyclone. Section 3 details the setup of the storm surge and wave models. Section 4 compares model results with measurments. Section 5 discusses the effects of a hypothetical intense storm on coastal structures and buildings.

\section{METEOROLOGICAL DATA}

In order to determine the sea surface air pressure 


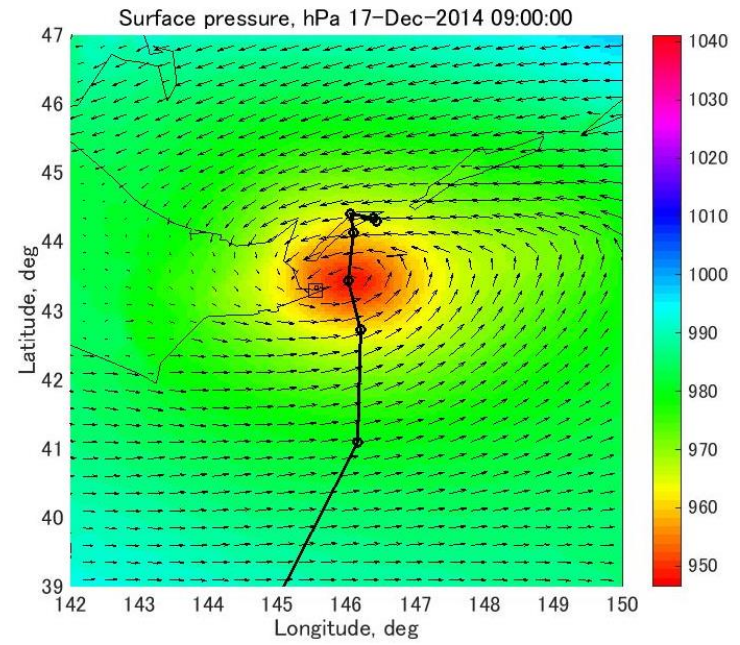

Fig. 1. Map of large model domain. Small rectangles represent the middle and small domains. Thick black line shows the storm track of Table 1. Color represents surface air pressure $[\mathrm{hPa}]$ and vectors show wind at 9am JST on December 17, 2014.

and wind fields during the cyclone, 3 different data sources were considered: Japan Meteorological Agency (JMA) Mesoscale Model (MSM) forecast data with $5 \mathrm{~km}$ resolution and available at $1 \mathrm{hr}$ intervals $^{6}$, JMA MSM reanalysis hindcast data with 5 $\mathrm{km}$ resolution and available at $3 \mathrm{hr}$ intervals ${ }^{7)}$, and Climate Forecast System Version 2 (CFSv2) data with $20 \mathrm{~km}$ resolution at $1 \mathrm{hr}$ intervals ${ }^{8}$. The validity of these model results were compared with AMEDAS $^{9)}$ weather station measurements at the 3 easternmost locations in Hokkaido: Attoko, Nemuro, and Nosappu. Fig. 2 compares measured air pressure, wind speed, and wind direction with each model's results. As the CFSv2 data's spatial resolution is too coarse, it cannot resolve the storm enough to hindcast the pressure and wind speed measured at the AMEDAS stations. However, the JMA MSM forecast and reanalysis data sets each qualitatively compare well to measured data from the AMEDAS stations. Therefore, JMA MSM reanalysis data is

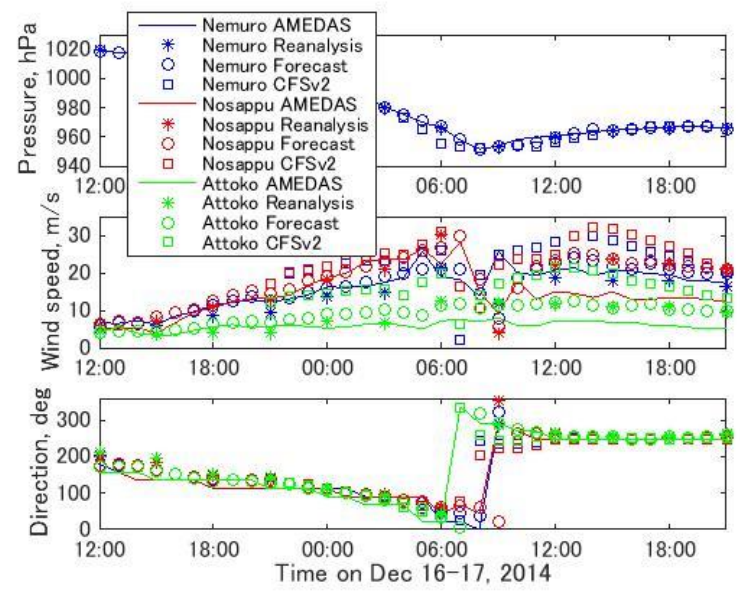

Fig. 2. Weather models compared to AMEDAS measurements. used to drive the storm surge model to follow. Fig. 1 shows the track of the cyclone along with sea level air pressure and wind fields at the time of lowest central pressure. Table 1 lists storm track parameters derived from the JMA MSM reanalysis data set, along with the track of a hypothetical storm with $150 \%$ the intensity of the Decemer 2014 Nemuro cyclone. This hypothetical storm is used as a proxy for the type of storm to which this region might be subject in the future due to climate change.

\section{STORM SURGE AND WAVE MODEL}

The hindcast pressure and wind fields are input into a combined hydrodynamic and wave model to hindcast the water level and wave heights induced by the cyclone. The hydrodynamic model used is Delft-3 ${ }^{10)}$ applied with only 1 layer in the vertical (thus the shallow water equations), and the spectral wave model used is SWAN ${ }^{11)}$. Delft-3D and SWAN are run together, with the hydrodynamic model repeatedly passing water level and current fields to the wave model, which calculates the wave field including the effects of currents and storm surge. The wave model in turn passes the radiation stress field back to the hydrodynamic model, which uses this information to calculate breaking-wave-induced setup and nearshore currents.

The Delft-3D/SWAN model was run over 3 nested domains, with the large domain of $2 \mathrm{~km}$ resolution, the middle domain $80 \mathrm{~m}$, and the small domain $16 \mathrm{~m}$ (Fig. 1). Coarse bathymetry from JODC ${ }^{12)}$ was combined with fine bathymetry from the Japan Coast Guard nautical chart of Nemuro Port ${ }^{13)}$ for the fine model domains. Land elevation in the model was derived from GSI $5 \mathrm{~m}$ mesh data ${ }^{14)}$. Tides were included as a boundary condition using the TPXO ${ }^{15}$ ) model result, and spun up for 5 days before adding winds to the model. Delft-3D was run with 1 vertical layer. Manning's $n$ for bed friction was specified as $n=0.1 \mathrm{~s} / \mathrm{m}^{1 / 3}$ in industrial areas, $n=0.15 \mathrm{~s} / \mathrm{m}^{1 / 3}$ in dense residential areas, and $n=0.02 \mathrm{~s} / \mathrm{m}^{1 / 3}$ over open

Table 1. Track of the December 2014 Nemuro cyclone based on JMA Reanalysis data ${ }^{7}$.

\begin{tabular}{|c|c|c|c|c|c|c|c|c|}
\hline Month & Day & Hour & $\begin{array}{c}\text { Center } \\
\text { Longitude, } \\
\text { deg E }\end{array}$ & $\begin{array}{c}\text { Center } \\
\text { Latitude. } \\
\text { deg N }\end{array}$ & $\begin{array}{c}\text { Center } \\
\text { Pressure, } \\
\mathrm{hPa}\end{array}$ & $\begin{array}{c}\text { Max } \\
\text { Wind, } \\
\mathrm{m} / \mathrm{s}\end{array}$ & $\begin{array}{c}\text { Center } \\
\text { Pressure } \\
150 \%, \\
\mathrm{hPa}\end{array}$ & $\begin{array}{c}\text { Max } \\
\text { Wind } \\
150 \%, \\
\mathrm{~m} / \mathrm{s}\end{array}$ \\
\hline 12 & 16 & 12 & 134.18 & 32.53 & 997 & 26.25 & 989 & 39.37 \\
\hline 12 & 16 & 15 & 136.50 & 33.42 & 990 & 30.19 & 978 & 45.28 \\
\hline 12 & 16 & 18 & 139.22 & 34.76 & 986 & 28.78 & 973 & 43.16 \\
\hline 12 & 16 & 21 & 142.46 & 36.48 & 982 & 30.37 & 966 & 45.55 \\
\hline 12 & 17 & 0 & 144.99 & 38.79 & 973 & 29.78 & 953 & 44.67 \\
\hline 12 & 17 & 3 & 146.17 & 41.09 & 957 & 32.97 & 929 & 49.45 \\
\hline 12 & 17 & 6 & 146.21 & 42.72 & 949 & 35.74 & 916 & 53.61 \\
\hline 12 & 17 & 9 & 146.03 & 43.43 & 948 & 33.67 & 916 & 50.50 \\
\hline 12 & 17 & 12 & 146.10 & 44.13 & 948 & 32.82 & 915 & 49.24 \\
\hline 12 & 17 & 15 & 146.07 & 44.41 & 950 & 29.15 & 919 & 43.73 \\
\hline 12 & 17 & 18 & 146.39 & 44.35 & 953 & 28.48 & 923 & 42.73 \\
\hline 12 & 17 & 21 & 146.45 & 44.30 & 955 & 26.88 & 925 & 40.32 \\
\hline
\end{tabular}




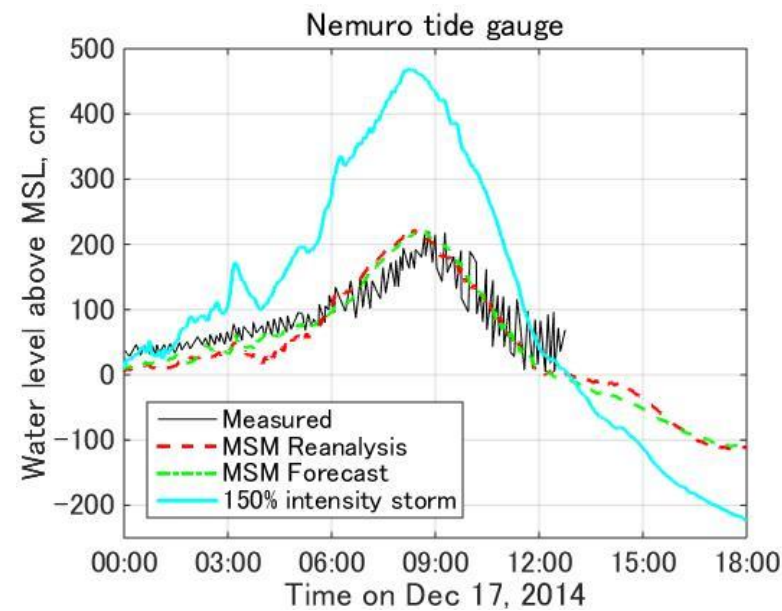

Fig. 3. Comparison of Delft-3D modeled water elevation with measurements from the Nemuro Port tide gauge ${ }^{21)}$.

ground $^{16), 17)}$. In order to evaluate the effect of this land-use-dependent Mannign's $n$, another simulation was run with uniform $n=0.02 \mathrm{~s} / \mathrm{m}^{1 / 3}$.

An important adjustment to the default SWAN setup was the use of an air-sea drag coefficient limiter of $0.003^{18), 19)}$ imposed on the drag law of $\mathrm{Wu}^{20)}$. This drag coefficient limiter is the result of multiple airborne sonde drop measurements in hurricanes ${ }^{19)}$, and is necessary to prevent the development of unphysical wave heights in the model.

\section{STORM SURGE MODEL RESULTS}

The water level measured by the Nemuro tide gauge $^{21)}$ is compared with storm surge model results in Fig. 3. The model result captures the peak storm tide at $2.2 \mathrm{~m}$ above mean sea level (MSL). The application of both JMA MSM meteorological models (forecast and reanalysis) drivers for the storm surge model result in almost the same storm tide timeseries at this location. Both model results hindcast a marginally more rapid rise in storm surge than the measurement, with a peak storm tide 30 minutes earlier than the measured timeseries. Since the tide

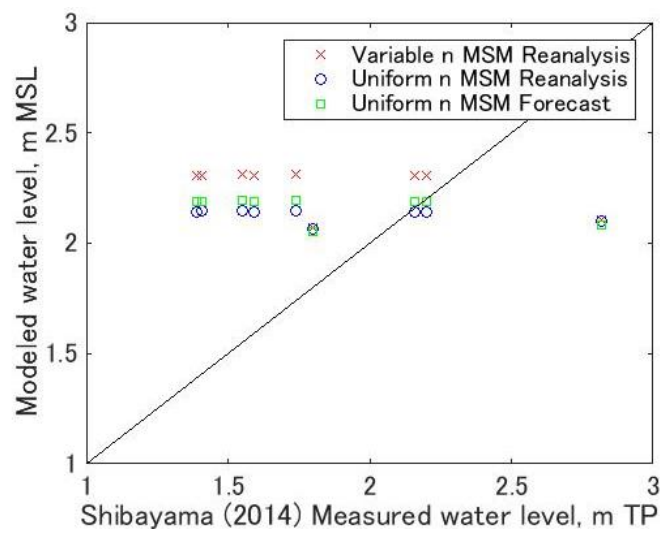

Fig. 4. Comparison of Delft-3D maximum modeled water elevations with the measurements of Shibayama et. al. ${ }^{22)}$.

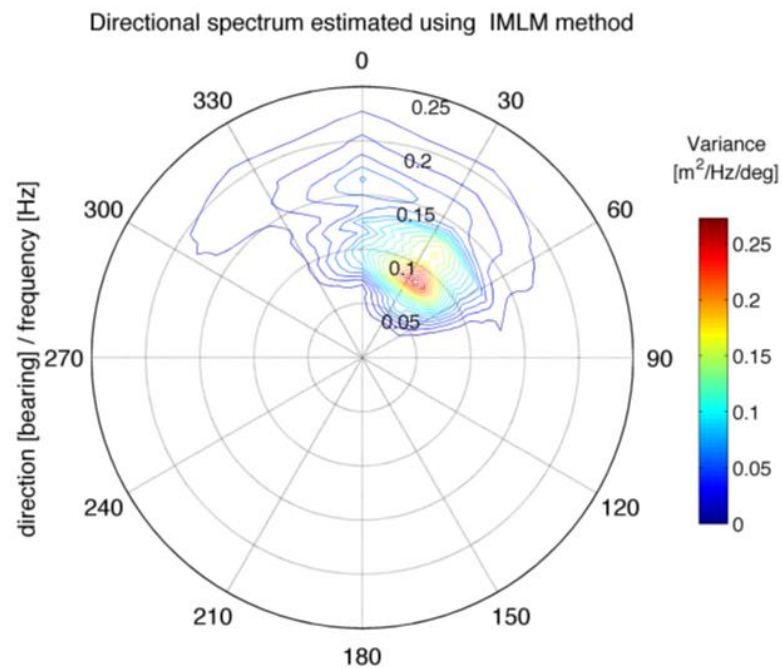

Fig. 5. SWAN wave height spectrum outside of Nemuro Port used as input to the BOSZ Boussinesq wave model. Radial bins are frequency [Hz], and azimuthal bins are incident wave direction [deg]. Figure made using the DIWASP toolbox for MATLAB.

gauge failed at about 1:00 pm, no measured data is available for comparison after that time.

Fig. 4 shows modeled inundation water levels compared with Shibayama et. al.'s ${ }^{22)}$ measurements throughout the inundated portion of Nemuro. The median value of the measurements is close to the model result, though the measurements show a larger spread. To investigate whether this could have been due to infragravity oscillations, the Boussinesq wave model $B O S Z^{23)}$ was applied to Nemuro with the same topography used by Delft-3D and with the spectrum of Fig. 5 as the offshore wave boundary condition ${ }^{24)}$. However, BOSZ computes only weak energy in the infragravity band. Therefore, the difference between modeled and measured flood elevations in Fig. $\mathbf{4}$ is likely due to variations in flow around individual buildings and structures in the town, as these buildings were not resolved in the topographic data used by the model.

Fig. 6 shows the maximum modeled flood depth throughout the town and harbor. The extent of inundation compares well with maps of observed inundation extent published by MLITT ${ }^{3)}$ and Watanabe et. al. ${ }^{25)}$. As indicated by Fig. 4, accounting for land-use-dependent bed friction had only a small effect on modeled inundation depth by retarding flow speed and causing a $10 \%$ deeper flood to accumulate on land than in the case with a uniform Manning's $n$.

Fig's 7 and 8 indicate that large waves did not penetrate into the flooded town. This is a reason for the lack of heavy damage and casualties due to the storm surge. However, by resolving individual waves with BOSZ, Fig. 8 indicates that wave runup east of the port was large enough to overtop a berm road and cause ponding that was not resolved by the 


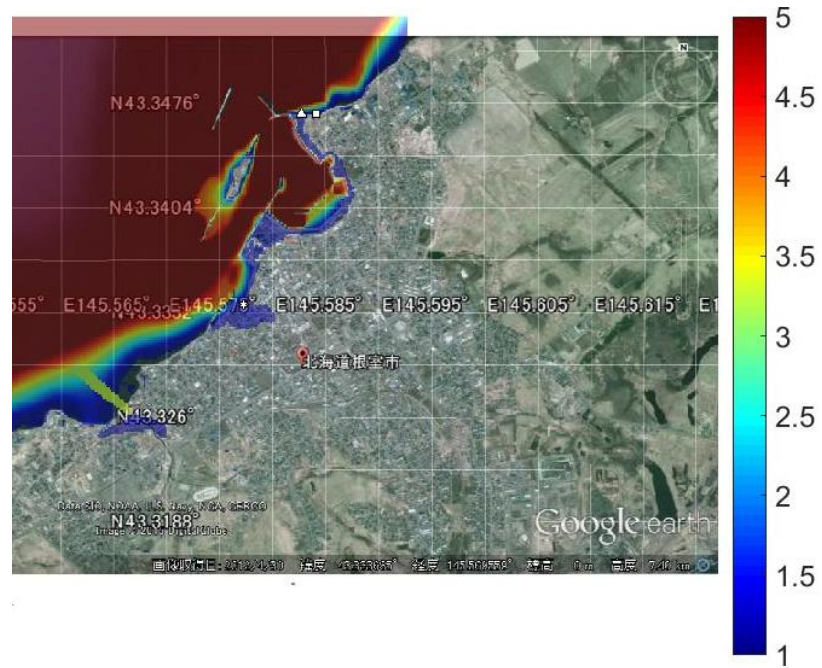

Fig. 6. Maximum Delft-3D flood depth [m] in Nemuro.

phase-averaged result of Fig. 6.

\section{URBAN HAZARD REASSESSMENT}

In order to assess the hazard that Nemuro and other towns fronted by shallow offshore regions at midlatitudes might face in the future due to climate change, a hypothetical storm with $150 \%$ the central pressure drop and maximum wind speed of the December 2014 Nemuro cyclone was considered (Table 1). Fig. 3 shows that this event would cause a storm surge up to $4.6 \mathrm{~m}$ above MSL, resulting in inundation of low-lying parts of town by water up to $4 \mathrm{~m}$ deep (Fig. 9). This storm surge would submerge the town's coastal defenses, which are mostly wave-dissipating concrete blocks (Fig. 10) along with breakwaters and floodwalls with heights between $2 \mathrm{~m}$ and $3 \mathrm{~m}$ above MSL. Waves would thus propagate into town (Fig. 11) with significant wave height of $2 \mathrm{~m}$ in the residential area of Fig. 10, and $4.5 \mathrm{~m}$ high waves would strike the breakwater north

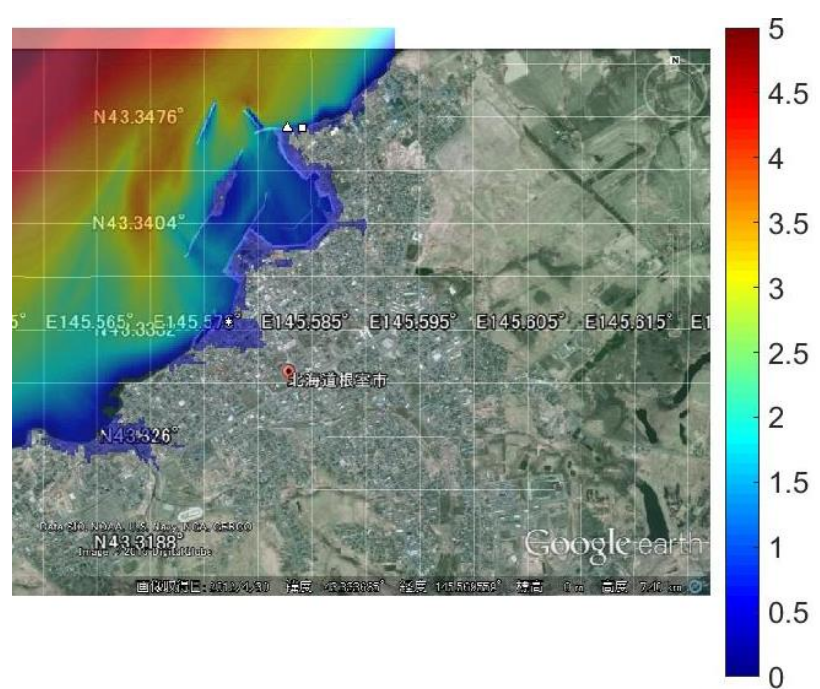

Fig. 7. Maximum SWAN significant wave height [m]

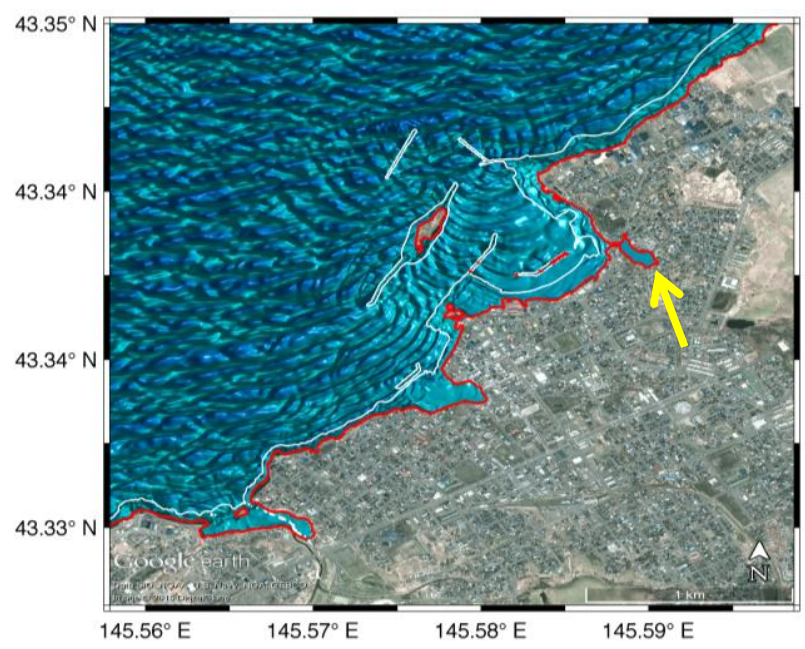

Fig. 8. Example snapshot of the wave field from the BOSZ Boussinesq-type wave model. White line indicates the mean sea level shoreline. Red line indicates maximum runup extent. Arrow indicates area of ponding due to wave runup and overtopping.

of the harbor. The propagation and breaking of waves of this size could pose a threat to the infrastructure protecting the town, and, even graver, to lives and property inside the town.

Armor stability was evaluated via Eq. (1) ${ }^{26), 27)}$ for tetropod-armored slopes and Eq. (2) ${ }^{26), 28)}$ for tetrapod mounds in composite breakwaters.

$$
\begin{aligned}
& \frac{H_{s}}{\Delta D_{n}}=\left(3.75 \frac{N_{o d}{ }^{0.5}}{N_{z}^{0.25}}+0.85\right) s_{o m}^{-0.2} \\
& \frac{H_{s}}{\Delta D_{n}}=2.32\left(\frac{N_{o d}}{N_{z}^{0.5}}\right)^{0.2}+1.33
\end{aligned}
$$

where $\Delta=\left(\rho_{\mathrm{s}} / \rho_{\mathrm{w}}-1\right)$, with $\rho_{\mathrm{s}}$ the solid (concrete) density, $\rho_{\mathrm{w}}$ the water density, $H_{s}$ the significant wave height, $D_{n}$ the armor unit equivalent cube side

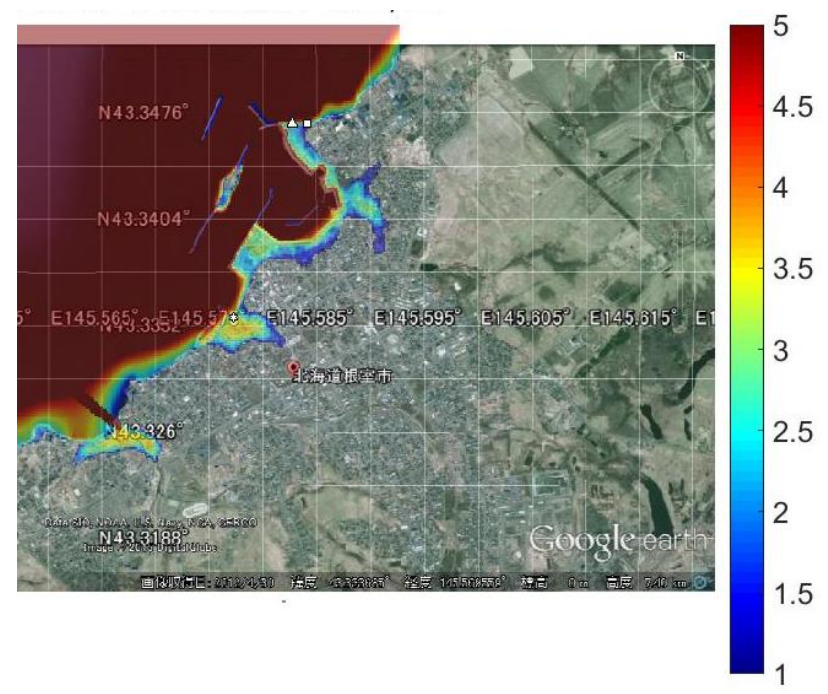

Fig. 9. Maximum Delft-3D flood depth [m] in Nemuro due to the hypothetical $150 \%$-intensity storm. 


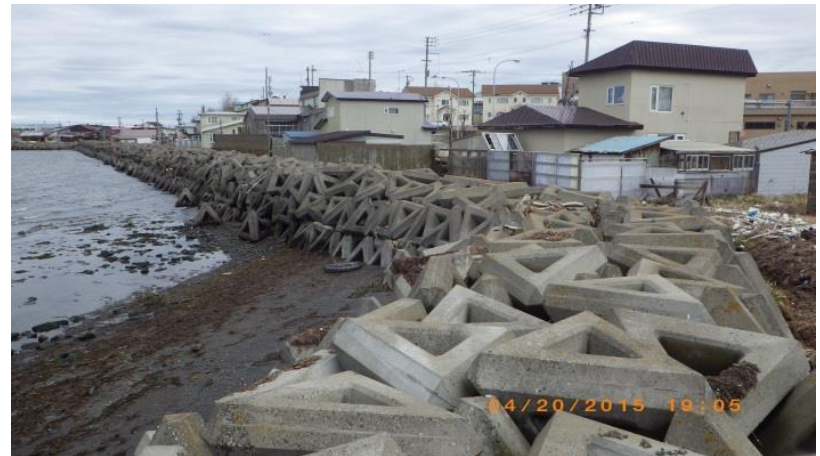

Fig. 10. Residential development at the location of the star icon in Figures 6, 7, 9, and 11.

length, $N_{z}$ the number of waves (equal to 7,500 for equilibrium damage), $s_{\text {om }}$ the wave steepness, and $N_{o d}$ is the number of units displaced out of the armor layer within a strip of 1 cube side length $D_{n}$.

The locations of the triangle and rectangle icons in Fig. 11, along with the entire northern attached breakwater, are composed of concrete jack-type wave dissipating blocks and tetrapods of length $2.4 \mathrm{~m}$ protecting concrete caissons and parapets. Even at the tip of the attached breakwater, where the significant wave height would be $4.5 \mathrm{~m}$, Eq. (2) gives $N_{o d}=0.13$, indicating that displacement of armor units would be minimal. The $1.5 \mathrm{~m}$ long tetrahedron-type armor units of Fig. 10 would be subject to a significant wave height of $2.5 \mathrm{~m}$, for which Eq. (1) gives $N_{o d}=0.16$. In both of these locations, the armor units in place appear to be large enough so as not to fail during the $150 \%$ intensity storm. However, the $4.6 \mathrm{~m}$ above MSL storm surge will allow waves to overtop these defenses and impact buildings directly.

The design maximum pressure $P$ and force $f$ per unit wall length due to a breaking wave incident on a vertical wall is calculated via Eq. $(3)^{29)}$ and Eq. (4) ${ }^{30)}$

$$
\begin{aligned}
& P=C_{p} \gamma_{w} d+1.2 \gamma_{w} d \\
& f=1.1 C_{p} \gamma_{w} d^{2}+2.4 \gamma_{w} d^{2}
\end{aligned}
$$

where $C_{p}$ is a dynamic pressure coefficient equal to 2.6 for residential buildings and 3.5 for essential facilities (hospitals, evacuation centers, etc.), $\gamma_{\mathrm{w}}$ is the specific weight of water, and $d$ is the water depth at breaking. The breaking water depth is assumed to be $d=H_{s} / 0.78$, with $H_{s}$ the significant wave height.

In the residential area of Fig. 10, waves of $2.5 \mathrm{~m}$ height breaking against building walls will result in $P=103 \mathrm{kPa}$ and $f=362 \mathrm{kN} / \mathrm{m}$. This loading is 2 orders of magnitude larger than would be occur due to wind even during category 5 hurricane conditions ${ }^{29)}$, so building collapses might be expected.

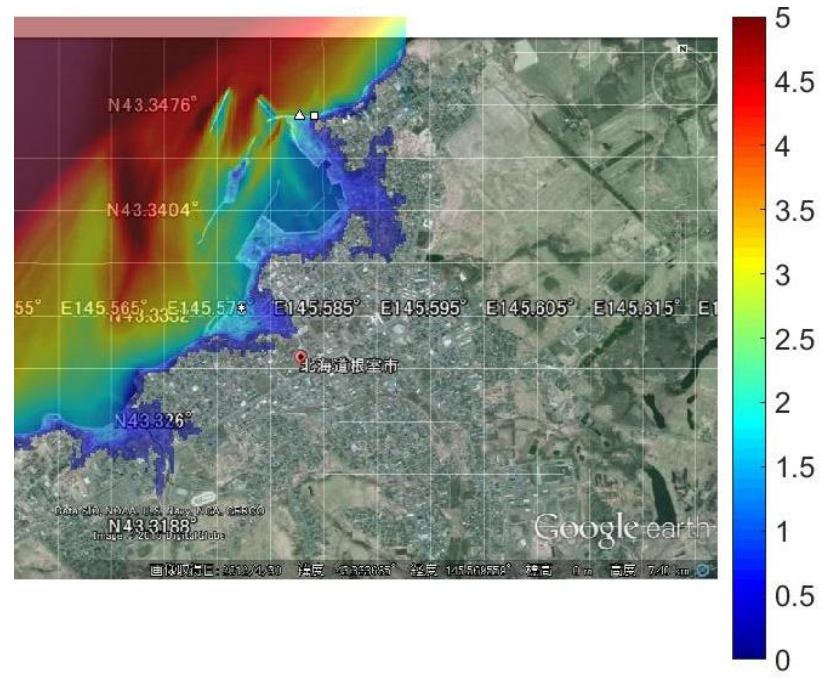

Fig. 11. Maximum SWAN significant wave height [m] in Nemuro due to the hypothetical $150 \%$-intensity storm.

Storm surge due to the December 2014 Nemuro cyclone was hindcast using a combined hydrodynamic and wave model with JMA MSM reanalysis meteorological data as the surface boundary condition. The model result agrees with published measurements of water level and inundation extent in the town. To evaluate the possible effects of climate change, a hypothetical storm with $150 \%$ the intensity of the 2014 cyclone was also simulated. Though the concrete armor units protecting the town's infrastructure are strong enough to escape damage from waves, they are not high enough to prevent waves from riding atop the storm surge into low-lying areas of the town proper and the harbor. Waves propagating into the town are large enough to wreck residential buildings and pose a threat to life safety.

The type of threat facing Nemuro is not limited to this city alone, but will also affect other cities fronted by shallow coasts in Hokkaido and elsewhere at northern midlatitudes. As hurricanes and typhoons migrate poleward due to climate change ${ }^{4)}$ and the intensities of extratropical storms near Hokkaido strengthen ${ }^{5)}$, the incidence of damaging storm surge and waves at these locations is likely to become more common. However, this does not necessarily suggest that building higher breakwaters and seawalls is a practical idea. Since the population of Nemuro is declining rapidly $(28,060$ residents in 2014 , compared to a peak of 49,896 residents in 1966) ${ }^{31}$, managed and gradual retreat of residences from the shoreline via land use zoning might be a more practical option than public investment in shoreline protection infrastructure. Protection of port infrastructure, however, will require construction of larger breakwaters, floodwalls and gates, or toughened or elevated buildings.

\section{CONCLUSIONS}

ACKNOWLEDGMENTS: The authors thank 
Celso Ferreira and Fabien Retif for their advice. This work was funded by an IRIDeS Tokutei Project grant, and by the JSPS-NSF Cooperative Program for Interdisciplinary Joint Research Projects in Hazards and Disasters, project entitled "Evolution of Urban Regions in Response to Recurring Disasters".

\section{REFERENCES}

1) Mainichi Newspaper: Strong blizzard in Nemuro, "downtown looks like the sea", storm surge causes $1.5 \mathrm{~m}$ deep flooding. Dec 17, 2014.

2) Asahi Newspaper: Flooding in Nemuro, chaos in Hokkaido, strong wind in western Japan, and first snow in Osaka. Dec 17, 2014.

3) MLITT: Response of the Hokkaido Development Office to blizzards and storm surges. Ministry of Land Infrastructure Transport and Tourism, Hokkaido Development Office. http://www.hkd.mlit.go.jp/kyokutyou/h26/0218/01.pdf. 2014.

4) Kossin, J.P., Emanuel, K.A., and Vecchi, G.A. The poleward migration of the location of tropical cyclone maximum intensity, Nature, v509, pp349-352, 2014.

5) Bengtsson, L., Hodges. K.I., and Keenlyside, N.: will Extratropical Storms Intensify in a Warmer Climate? Journal of Climate. vol. 22, pp. 2276-2301, 2009.

6) Japan Meteorological Business Support Center: Mesoscale GPV MSM forecast data. http://www.jmbsc.or.jp/hp/online/f-online0c.html and http://database.rish.kyoto-u.ac.jp/arch/jmadata/gpv-latest.ht $\mathrm{ml}$. Accessed December 2014.

7) Japan Meteorological Business Support Center: Mesoscale GPV MSM reanalysis data. http://www.jmbsc.or.jp/hp/offline/cd0380.html. CD-ROM released January 2015.

8) National Center for Atmospheric Research: NCEP Climate Forecast System Version 2 (CFSv2) Selected Hourly Time-Series Products. http://rda.ucar.edu/datasets/ds094.1/. Accessed 11 Mar 2015.

9) Japan Meteorological Agency: AMEDAS hourly weather station measurements. http://www.data.jma.go.jp/obd/stats/etrn/index.php. Accessed February 2015.

10) Deltares, Delft3D-FLOW User's Manual. Version 3.15, 2011.

11) Booij, N., R. Ris and Holthuijsen, L.: A third-generation wave model for coastal regions, Part I, Model description and validation. Journal of Geophysical Research 104 (C4): 7649-7666, 1999.

12) Japan Oceanographic Data Center: 500-m mesh depth data. http://jdoss1.jodc.go.jp/cgi-bin/1997/depth500_file.jp. Accessed February 2015.

13) Japan Coast Guard. Plans on the Nemuro Hanto. Oct 2005.

14) Geospatial Information Authority of Japan: 5-m mesh survey data. http://fgd.gsi.go.jp/download/. Accessed February 2015.

15) TPXO: The OSU TOPEX/POSEIDON Global Inverse Solution. http://volkov.oce.orst.edu/tides/global.html, 2014.

16) Bunya, S., Deitrich, J.C., Westerink, J.J., Ebersole, B.A., Smith, J.M., Atkinson, J.H., Jensen, R., REsio, D.T., Luettich, R.A., Dawson, C., Cardone, V.J., Cox, A.T., Powell, M.D., Westerink, H.J., and Roberts, H.J. A High-Resolution Coupled Riverine Flow, Tide, Wind, Wind Wave, and Storm Surge Model for Southern Louisiana and
Mississippi. Part I: Model Development and Validation. Monthly Weather Review. Vol. 18, pp. 345-377, 2010.

17) Bricker, J., Gibson, S., Takagi, H., and Imamura, F. On the Need for Larger Manning's Roughness Coefficients in Depth-Integrated Tsunami Inundation Models. Coastal Engineering Journal. DOI: 10.1142/S0578563415500059, 2015.

18) Dietrich, J.C., Westerink, J.J., Kennedy, A.B., Smith, J.M., Jensen, R.E., Holthuisjen, L.H., Dawson, C., Luettich, R.A. Jr., Powell, M.D., Cardone, V.J., Cox, A.T., Stone, G.W., Pourtaheri, H., Hope, M.E., Tanaka, S., Westerink, L.G., Westerink, H.J., and Cobell, Z.: Hurricane Gustav (2008) waves and storm surge: hindcast, synoptic analysis, and validation in southern Louisiana, Monthly Weather Review, Vol. 39, pp. 2488-2522, 2011.

19) Powell, M. D.: Drag coefficient distribution and wind speed dependence in tropical cyclones. Final report to the NOAA Joint Hurricane Testbed (JHT) Program, 26 pp, 2006.

20) Wu, J.: Wind-Stress Coefficients Over Sea Surface From Breeze to Hurricane, Journal of Geophysical Research, Vol. 87, No. C12, pp. 9704-9706, Nov. 20, 1982.

21) Japan Meteorological Agency: Nemuro tide gauge measurement.

http://www.jma.go.jp/jp/choi/graph.html?areaCode=202\&p ointCode $=101803 \&$ index $=3$. Accessed December 2014 .

22) Shibayama, T., Mikami, T., Nakamura, R., Matsuba, S., Iwamoto, T., Mall, M., Jin, J., Tatekouji, A., and Tanoukura, Y. Field survey report of the December 17, 2014 Nemuro, Hokkaido storm surge. http://www.f.waseda.jp/shibayama/disaster/documen t/2014Nemuro/Nemuro\%20report_Final\%20english \%20version.pdf. 2014.

23) Roeber, V., and Cheung, K.F.: Boussinesq-type model for energetic breaking waves in fringing reef environments. Coastal Engineering, Vol.70(1), pp.1-20, 2012.

24) Roeber, V., and Bricker, J.D. Destructive tsunami-like wave generated by surf beat over a coral reef during Typhoon Haiyan. Nat. Commun. Accepted for publication, 2015.

25) Watanabe, Y., Saruwatari, A., Lima, A., Nikkawa, S., Kato, M. 2014 Nemuro storm surge survey press release. Hokkaido University. http://www.hokudai.ac.jp/news/141225_pr_eng.pdf. 2014.

26) US Army Corps of Engineers: Coastal Engineering Manual. EM 1110-2-1100 (Part VI). June 2006.

27) van der Meer, J. W.: Stability of Cubes, Tetrapodes and Accropodes, Proceedings of the Breakwaters '88 Conference; Design of Breakwaters, Institution of Civil Engineers, Thomas Telford, London,UK, pp 71-80. 1988.

28) Hanzawa, M., Sato, H., Takahashi, S., Shimosako, K., Takayama, T., and Tanimoto, K.: New Stability Formula for Wave-Dissipating Concrete Blocks Covering Horizontally Composite Breakwaters, Proceedings of the 25th International Coastal Engineering Conference, American Society of Civil Engineers, Vol 2, pp 1665-1678. 1996.

29) American Society of Civil Engineers: Minimum Design Loads for Buildings and Other Structures. ASCE-7, 2003.

30) Federal Emergency Management Agency: Coastal Construction Manual. FEMA P-55, Vol. 2, Aug. 2011.

31) Nemuro City: Population and housing trend. http://www.city.nemuro.hokkaido.jp/dcitynd.nsf/doc/a4080 55c9be31b574925710d00007962?OpenDocument. Accessed May 2015.

(Received March 18, 2015) 